\title{
Redactioneel
}

Chantal Bax

ANTW 109 (2): 169

DOI: 10.5117/ANTW2017.2.BAXC

Aan het einde van de afscheidsrede die Martin Stokhof in mei 2016 hield, gaf hij het laatste woord aan anderen; zijn presentatie eindigde met foto's van de vele mensen met wie hij, in allerlei hoedanigheden, heeft samengewerkt. Dit is tekenend voor iemand die juist altijd veel achter de schermen voor de filosofie heeft gedaan. Naast zijn belangrijke werk op het gebied van de semantiek en de Wittgenstein interpretatie, zette Stokhof zich onvermoeid en onbaatzuchtig in voor collega's, AiO's en studenten, maar ook voor instituten als het ILLC, NWO en ERC. Met dit focusnummer, waarvan het centrale artikel is gebaseerd op zijn afscheidsrede, komt Stokhof weer eens zelf in het middelpunt van de belangstelling te staan. Ook dit forum gebruikt hij echter kenmerkenderwijs om zich hard te maken voor de filosofie. Hij schetst de uitdaging die het naturalisme vormt voor de geesteswetenschappen in het algemeen en de filosofie in het bijzonder, en legt met behulp van Wittgenstein en het begrip 'niet-discursieve inhoud' uit dat er, zelfs met alle wetenschappelijke en technologische ontwikkelingen van vandaag de dag, nog altijd een eigen plaats is voor de academische filosofie. Het focusartikel wordt vervolgens kritisch besproken door een zestal commentatoren, maar het laatste woord is in dit nummer wel voor Stokhof zelf. De redactie bedankt hem ook dit keer voor zijn belangwekkende bijdrage.

\section{Chantal Bax}


